УДК 340.12:321

DOI https://doi.org/10.32837/yuv.v0i1.2079

Н. Атаманова,

кандидат юридичних наук, доцент,

доцент кафедри державно-правових дисциплін

Міжнародного гуманітарного університету

\title{
ДИСКУСІЙНІ ПОГЛЯДИ НА ПОНЯТТЯ ТА ВИДИ ФОРМ ДЕРЖАВНОГО РЕЖИМУ
}

Постановка проблеми. На сучасному етапі сформувались дискусійні питання щодо поняття «форма державного режиму», адже воно сформувалось у процесі суспільнополітичного розвитку загалом і було відображене у результаті пізнавальної діяльності науковців зокрема. Наявність значної кількості різних поглядів на дефініцію і зміст поняття та видів форм державного режиму на сучасному етапі розвитку юридичної науки свідчить про певну гносеологічну проблемність і відповідно актуальність цього питання.

Загалом форма держави як одне 3 основних явищ державно-організованого суспільства завжди була предметом наукового інтересу. Так, це питання знайшло відображення в дослідженнях таких учених, як: Є. Білозьоров, В. Власенко, О. Горова, А. Завальний, Н. Заяць, А. Венгеров, С. Комаров, О. Котюк, М. Марченко, О. Скакун, А. Черданцев, Ю. Оборотов тощо. Тому розуміння форми держави як системного державно-правового явища стало актуальним і водночас дискусійним питанням. Водночас питання державного режиму, його форм та видів потребують подальшого дослідження в теоретичній площині.

Метою статті $€$ аналіз різноманіття поглядів щодо дефініції поняття і видів форм державного режиму.

Постановка завдання. Це дослідження порушило проблемні питання, розуміння яких потребує або ж під- твердження вже традиційного знання щодо системності форм державного режиму, або його спростування.

Виклад основного матеріалу. Під час історичного розвитку держави починається період, коли їі нова якість (тобто зміст та сутність) не вміщаються у рамки вже старої форми. Саме тоді здійснюється заміна форм новим змістом, водночас виникає нова форма, яка адекватна в новому змісті і відображає ї сутність. Проте зміна старої форми держави проходить тільки у разі сформованості певних умов у самому суспільстві. Й хоча спочатку змінюється сам зміст, а вже потім форма, все ж допускається можливість того, що нову форму можна використати задля збереження старого змісту. У такому разі проходить внутрішня трансформація цієї форми, що із метою застосування в обслуговуванні старого змісту певним чином видозмінюється, й, навпаки, своєрідне штучне використання старої форми для відображення нового, вже прогресивного змісту, тобто підлаштування iï під деякі суб'єктивні потреби робить сповільнення процесу гармонійного розвитку всіх сфер суспільного життя, гальмує процес становлення суспільних відносин нового формату. Вважаємо, що зазначені положення мають особливе значення не лише для глибшого й усебічного розуміння самого змісту і сутності аналізованого державно-правового явища, а також з'ясування його термінологічного еквіваленту, тобто термінів 


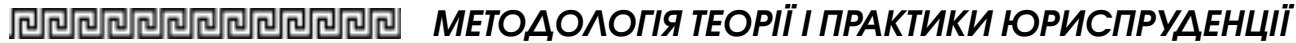

«форма державного режиму», а не «державне правління», яке інколи застосовується [1, с. 54], але й для визначення класифікаційних рівнів, окреслення нових різновидів форм державного режиму і зокрема розуміння його сутності. Відзначимо, що сучасний розвиток суспільних відносин у політичній галузі і еволюція відповідних владних інститутів призводить до того, що сам зміст та сутність наявної у державі організації державної влади вже не відповідає визначеній, традиційній формі правління. Саме тому сутнісні та більш змістові політико-правові ознаки структури влади, які виявляються у збільшеній сукупності країн і свідчать про зміну ii якості, що уже не входить у звичні традиційні форми державно-владної організації, й цим зумовлюють необхідність виділення нових форм державного режиму, визначення відповідної теоретичної бази, й відповідно, конституційного його закріплення задля результативної та дієвої політичної практики зокрема.

Так, певним системним середовищем форми державного режиму $€$ форма держави, й тому буде доцільним зупинитись на аналізі позицій учених стосовно змістового навантаження, а також цілісності і системності такого явища й відповідно наявності його складових елементів і їхніх зв' язків.

Нині є кілька точок зору на саму форму держави. Приміром, одні вчені вважають, що форма держави у загальному сенсі розуміється як певний спосіб правління та державного устрою, а в більш вузькому лише як форма правління [2, с. 18]. Водночас позиція інших учених полягає у тому, що форму держави вони визначали як своєрідну організацію політичної влади у ній, взяту у єдності іiі таких трьох головних елементів: форми правління, державного устрою та політичного режиму. Таку думку підтримує О. Котюк, який відзначав, що форма будь-якої країни проявля- ється, зокрема, в організації верховної влади у ній, тобто у самій формі правління, а вже організація інших органів державної влади (таких як місцеві, виконавчі органи) охоплюється поняттям «форма правління» тільки тією мірою, яка у їхньому устрої проявляє непохідний та первинний характер їх права на здійснення самої влади [3, с. 87]. На нашу думку, правильною є позиція, що до форми правління не варто включати увесь обсяг організації органів влади та зокрема управління, а також розмежовувати компетенцію між цими органами, як це інколи пропонувалося [5, с. 41], адже таке доволі розширене поняття «форма правління» призведе до його ототожнення із поняттям «механізм держави». Крім того, третьою стороною форми держави О. Котюк називав політичний режим як певну сукупність методів, які характеризують саму систему зв'язку державної влади із населенням, а також зміст політичних прав і свобод останнього, й зокрема відповідний спосіб вираження демократії. У цьому змісті поняття режиму виступає значно вузьким порівняно із формою держави та входить до неї як деяка частина цілого, хоча, на відміну від цих двох елементів, володіє більшою автономією [3, с. 107].

Слід відзначити, що й досі ці погляди О. Котюк знаходять підтримку серед деякого кола вчених, адже вони відображають саму форму держави як системну цілісність таких трьох елементів, як форми державного правління, державного устрою та політичного режиму, що віддзеркалюють доволі істотні ознаки держави як певної структурної територіальної та політичної організації самого суспільства.

Щодо питання визнання політичного режиму третім елементом форми держави, то одні вчені схиляються до думки, що саме політичний режим визначає не форму, а лише сутність держави [6], другі - методи так 
званого класового панування, і тому начебто не стосується форми держави [7], треті науковці сприймають його ширше порівняно із формою останньої, адже такий режим здійснюється не лише органами держави, а $з$ допомогою всієї системи диктатури цього класу [8].

Також варто відзначити, що структурна побудова держави, де у системі елементів іiі форми віддається перевага політичному режиму, адже він напряму пов'язаний із соціальною сутністю самої держави, на наш погляд, виглядає доволі обгрунтованою, й на цьому варто б зупинитись. Однак є питання, відповідь на яке не дає змоги йти далі у вирішенні проблеми структури форми держави. I це питання про те, чому саме у теорії держави та права разом із поняттям «Політичний режим» використовуються такі поняття, як «державний режим», «державний (політичний) режим», «політико-державний режим» [4, c. 40].

Таке дискусійне питання, на наш погляд, породжене відсутністю певного диференційованого підходу щодо пізнання «режимів» зі сторони різноманітних галузей державознавства, зокрема, політології та теорії держави й права. Нині більшість представників теоретико-правової науки вже по традиції вважають елементом форми держави саме політичний режим. Проте нами тут виявлена проблема, яку можна вирішити методом диверсифікації самого процесу пізнання режиму як своєрідного соціального явища. На нашу думку, термін «політичний режим» повинне позначати поняття, що у більш широкому значенні показує систему способів, методів, засобів та прийомів у здійсненні політичної влади зі сторони всіх суб'єктів політичної системи суспільства. Так, форма політичного режиму - це насамперед система способів та методів здійснення політичної влади, що $€$ результатом виявленої в певній соціальній практиці сукупної вольової дії державної, суспільно-політичної та іншої соціальної сили. Водночас політичний режим, зокрема, володіє своєю структурою: він складається із двох доволі владних підсистем, що за своїми суб'єктами породжують різноманітні види політичних режимів. I той, що $є$ результатом дій ширшого кола соціальних сил, логічним буде назвати соціально-політичним режимом, а той режим, що виступає результатом функціонування державних органів, - державно-політичним. Тобто поняття «соціально-політичний режим» $\mathrm{i}$ «державно-політичний режим» варто розрізняти як різноманітні структурні рівні одного явища та як предмети пізнання різних наук: у першому випадку - політології, у другому - юриспруденції (теорія держави і права та конституційне право).

Також можна підкреслити, що остання є структурно впорядкованою державно-правовою системою, що по факту складається із чотирьох владних підсистем, що утворюють одне ціле.

Отже, державний режим, підкреслимо, в юридичній площині означає сам ступінь участі державно-організованого суспільства у здійсненні публічної влади й забезпеченні власних головних принципів. На наш погляд, саме державний режим як поняття означає не так сукупність певних методів та засобів здійснення публічної влади в окремому суспільстві, як сам ступінь здійснення такої влади цим суспільством.

Саме тому серед ознак (деяких аспектів) державного режиму варто виділити такі. По-перше, порівняно з формою правління, що виражає саму організацію влади на національному (тобто загальнодержавному) рівні, то вже державний режим торкається лише організації та здійснення всієї публічної влади на всіх рівнях. I при тому, коли на національному рівні його індикатором виступає ступінь концентрації таких владних ресурсів, 


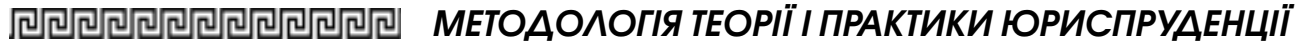

то вже на регіональному і місцевому рівні - це ступінь розвитку якраз місцевого самоврядування (включає місцеву демократію) [5, с. 84]. Водночас у недемократичній державі місцевий гауляйтер чи партійний секретар або ж представник окремого президента звичайно керує всіма місцевими справами, а вже місцеве самоврядування як відповідний інститут відсутнє взагалі. Тобто йдеться про те, що існує ступінь поділу певної публічної влади і по так званій «горизонталі» (а саме між гілками влади), і по «вертикалі».

Водночас про цілісність та системність самої форми держави свідчать і ї види. Нині форма держави поділяється на монократичну, полікратичну (поліархічну) й сегментарну [7, с. 89]. Проте на це питання теж $є$ дискусійні погляди науковців. Адже аналіз літературних джерел показав, що в них йдеться про види форми правління, види форми державного устрою, види політичного режиму, проте мало йдеться про види форм державного режиму.

Відзначимо, що для монократичної форми, що характерна в державі традиційного (тобто станово-класового) суспільства, присутня концентрація та централізація влади у межах одного інституту, тобто здебільшого однієі особи [6, с.76]. Також цій формі притаманна деяка нерозвиненість, тобто відсутність громадянського суспільства, яка і позбавляє (деякою мірою обмежує) громадян можливості впливати на сам політичний процес у державі. Оскільки форми участі населення в політичному житті зазвичай примусові, а місцеве самоврядування практично відсутнє. Під час монократичної форми держави установлюються недемократичні режими, які опираються на деяке насильство, примус, державну ідеологію чи релігію. А права і свобода громадян можуть декларуватись, проте насправді на практиці не гарантуються.

Щодо полікратичної форми державного режиму, то вона притаманна державі громадянського суспільства, і визначається поділом влади по горизонталі і вертикалі, а також більш стійким плюралізмом певних соціальних груп та інтересів, і формуванням своєрідного механізму стримувань i противаг, який і нейтралізує можливості деякої узурпації влади. У цій формі державного режиму економіка відділена від політики, а ресурси влади розділені між різноманітними спільнотами (що включає бізнесменів, фермерів, промисловців, профспілки, еліту тощо), які змушені погоджувати власні інтереси в процесі прийняття політичних рішень [7, с. 69]. У полікратії є доволі високий ступінь автономності певних територій. Також інститути державної влади формуються самим населенням шляхом вільного вибору, а окремі із них, які залишилися від старого суспільства (та старого змісту держави), є лише своєрідною даниною традиції та серйозної впливової ролі вже не відіграють. У таких державах існує конкурентна партійна система, яка показує інтереси різноманітних прошарків суспільства, а також гарантує права й свободи громадянина. Тобто полікратія - це зокрема модель форми сучасної держави, а також стратегічна іiі лінія розвитку загалом.

I ще одна сегментарна державна форма - це перехідна від монократичної до полікратичної форми державного режиму. Ця форма включає формальний поділ державної влади, зосереджує владу у руках певного глави держави чи уряду (тобто монарха у дуалістичних монархіях чи президента у так званих «суперпрезидентських» республіках). Також у ній відсутня самостійність самоврядних органів суб'єктів федерації, а в державно-правовому режимі домінує авторитарний метод управління (тобто заборони чи обмеження). Така форма має власні різновиди: до держав, які тягнуться до монократичної форми, належать Йорданія, Марокко, Таїланд; до полікратичних - Польща, Чехія [8, с. 43]. 
Отже, із наведеного варто узагальнити, що державний режим як категорія означає певний ступінь участі суспільства у здійсненні публічної влади і зокрема забезпеченні своїх головних принципів (тобто фундаментальних цінностей). Крім того, державний режим проявляється у механізмах легітимації публічної влади зі сторони суспільства, ефективності такого механізму тощо. Також критеріями для його видової класифікаціï державного режиму виступають насамперед такі його понятійні елементи (тобто критеріі), як: ступінь забезпечення прав людини, народовладдя, дієвість верховенства права, рівень певної відкритості публічної влади й гарантії для активного громадянського суспільства тощо.

Висновки та перспективи дослідження. Отже, підсумовуючи наведене, дійшли висновку, що форма держави виступає структурно впорядкованою цілісністю, а також iii підсистемою, що віддзеркалює як політичні, так і структурно-інституціональні й територіальні особливості організації зокрема і функціонування державної влади загалом.

Також для сучасної теорії держави й права у контексті аналізу форми державного режиму найбільш коректним видається застосування поняття державно-правового режиму, адже саме воно дозволяє у формальний спосіб описати не тільки державу саму по собі, а зі сторони ї взаємодії із правом і тієї системи відносин, що утворюються між державою та правом. Досить важливою складовою частиною самого змісту поняття «державний режим» $є$ те, що воно дає змогу дослідити форму держави не лише у світлі самого процесу набуття, розвитку й практичної реалізації публічної влади, але і в кореляціï iï з правом, праворозумінням, правотворчістю й правозастосуванням загалом. У результаті цього загальне поняття форми державного режиму отримує доволі важливий вимір, яким
$€$ його взаємозв'язок із правом. Тож поділяючи у цьому питанні позицію більшості вчених, відзначимо, що форму держави поділяють на монократичну, полікратичну (поліархічну) й сегментарну. Тому дослідження форми певної держави повинне здійснюватися з урахуванням усього комплексу чинників, що впливали на ii установлення та розвиток. Лише у цьому разі можна виявити доволі істинні закономірності встановлення окремої форми держави, іï неповторність та зокрема належність до деякої класифікаційної групи. I саме такий комплексний підхід $€$ перспективним для подальших досліджень.

У статті розглянуто поняття «рорма державного режиму», яке сформувалося під час суспільнополітичного розвитку та було розкрите у результаті пізнавальної діяльності у багатьох поколіннях державознавиів. Наявність різноманіття самих поглядів щодо його дефініції й змісту на mеперішньому етапі розвитку юридичної науки i свідчить про гносеологічну проблемність $і$ зокрема актуальність иього питання. Велике значення у cmammi має єдність як теоретичного, так і практичного у пізнанні форми державного режиму, адже зумовлене необхідністю комплексного дослідження його двох складників - юридичного та політичного (фактичного). Також автором показано, щзо динаміка політичного життя та сочіально-практичні аспекти в організаціі i реалізації державної влади виступає предметом вивчення багатьох наук. Тому доцільно у межах цього дослідження звернути увагу на дискусійні питання в теоретичній площині з урахуванням як історичного, так $i$ практичного аспектів, які дали змогу побудувати більш иілісне уявлення щодо форми державного режиму сучасної країни як історично зумовленої 


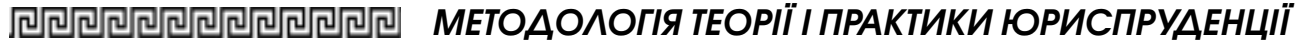

політико-правової владної цілої системи, що зовнішньо віддзеркалюе $i$ зміст, $i$ сутність держави та проявляється у його загальнотеоретичних, конституційних ma nолітичних сферах. У статmi теоретичного уточнення набуло дискусійне питання, пов'язане із виявленням місия та ролі форми державного режиму у системі елементів форми самої держави. Ретельному науковому аналізу та осмисленню, а також узагальненню піддалось питання, яке не охоплюються більш усталеними традииійними схемами та уявленнями. Дискусійним є питання категорії «форма державного режиму», для визначення якої автором розглянуто різноманітні погляди, оскільки у сучасній юридичній літеpamyрі немає його одностайності. Розглянуто класифікацію форм державного правління, яке теж має різне трактування. Здійснено установлення самої сутності та правових ознак сучасних різновидів форми державного режиму, його поняття, яке на рівні дефінітивного формулювання у теперішніх умовах вимагає суттевого уточнення та узагальнення.

Ключові слова: поняття, види форм, форма та зміст, форма державного правління, державний режим.

Atamanova N. Discussion views on the concepts and types of forms of state regime

The article considers the concept of "form of state regime", which was formed during the socio-political development and was revealed as a result of cognitive activity in many generations of political scientists. The presence of a variety of views on its definition and in particular the content at the present stage of development of legal science and indicates the epistemological problems and in particular the relevance of this issue. Of great importance in the article is the unity of both theoretical and practical knowledge of the form of the state regime, because it is due to the need for a comprehensive study of its two components - legal and political (actual). The author also shows that the dynamics of political life and in particular the sociopractical aspects in the organization and implementation of state power is the subject of study of many sciences. Therefore, it was expedient in this study to pay attention to the debatable issues in the theoretical plane, taking into account both historical and practical aspects, which allowed to build a more holistic view of the state regime of the modern country as a historically determined political and legal power system, which externally reflects and the content and essence of the state and is manifested in its general theoretical, constitutional and political spheres. The article clarified the theoretical issue related to the identification of the place and role of the form of the state regime in the system of elements of the form of the state itself. Careful scientific analysis and understanding, as well as generalization, have been the subject of a question that is not covered by more established traditional schemes and ideas. The question of the category "forms of state regime" is debatable, for the definition of which the author considered various views, because in the modern legal literature there is no unanimity. The classification of forms of government, which also has different interpretations, is considered. The establishment of the very essence and legal features of modern varieties of the state regime, its concept, which at the level of definitive formulation in the current conditions requires significant clarification and generalization.

Key words: concepts, types of forms, form and content, form of government, state regime. 


\section{Література}

1. Бостан С.К. Форма правління сучасної держави: проблеми історії, теорії, практики : монографія. Запоріжжя : Юрид. iн-m, 2005. 540 c.

2. Бостан С.К., Гусарєв С.Д., Пархоменко Н.М., Бостан Л.М., Заяць Н.В. Теорія держави $і$ права : навчальний посібник. Київ : Академія, 2013. 346 с.

3. Котюк О.В. Загальна теорія держави і права: навчальний посібник. Київ : Атіка, 2005. 592 c.

4. Процююк I.В. Форма $i$ зміст у понятті «форма державного правління». Юридичний науковий електронний журнал. № 5. 2015. С. 38-42.
5. Рабінович П.М. Основи загальної теорії права та держави : навчальний посібник. 5-те вид., зі змін. Київ : Атіка, 2001. 176 c.

6. Рудич Ф.м. Політологія : підручник. 3-те вид., перероб., доп. Київ : Лuбiдь, 2009. 480 c.

7. Скакун О.Ф. Теорія права і держави : підручник. 4-те, вид. допов. і перероб. Київ : Правова єдність : Алерта, 2014. 524 с.

8. Теорія держави та права : навчальний посібник. / Є.В. Білозьоров, В.П. Власенко, О.Б. Горова, А.М. Завальний, Н.В. Заящь та ін. ; за заг. ред. С.Д. Гусарєва, О.Д. Тихомирова. Київ: НАВС, Освіта України, 2017. 320 с. 